\title{
Professional burnout among nursing personnel employed in selected mental health departments in Poland
}

\section{Zjawisko wypalenia zawodowego personelu pielęgniarskiego zatrudnionego na wybranych oddziałach psychiatrycznych w Polsce}

\author{
Aleksandra Łucja Łopatkiewicz, ${ }^{1,2,-F}$ \\ ${ }^{1}$ Department of Public Health, Medical University of Warsaw, Warsaw, Poland \\ ${ }^{2}$ Masovian Voivodeship Hospital "Drewnica", Ząbki, Poland \\ A - research concept and design; $\mathrm{B}$ - collection and/or assembly of data; $\mathrm{C}$ - data analysis and interpretation; \\ $D$ - writing the article; $E$ - critical revision of the article; $F$ - final approval of the article
}

Pielęgniarstwo i Zdrowie Publiczne, ISSN 2082-9876 (print), ISSN 2451-1870 (online)

Piel Zdr Publ. 2020;10(1):19-26

Address for correspondence

Aleksandra Łucja Łopatkiewicz

E-mail: golabek.aleksandra@gmail.com

Funding sources

None declared

Conflict of interest

None declared

Received on November 27, 2018

Reviewed on January 3,2019

Accepted on March 4, 2019

Cite as

topatkiewicz At. Professional burnout among

nursing personnel employed in selected mental health departments in Poland. Piel Zdr Publ. 2020;10(1):19-26. doi:10.17219/pzp/105341

DOI

10.17219/pzp/105341

Copyright

○ 2020 by Wroclaw Medical University

This is an article distributed under the terms of the

Creative Commons Attribution 3.0 Unported License

(https://creativecommons.org/licenses/by/3.0/)

\begin{abstract}
Background. Professional burnout occurs under circumstances of chronic stress and applies mostly to occupational groups whose work entails direct contact and close interpersonal involvement with people. Professional burnout is a consequence of dissonance between the person and the work environment. It is a multidimensional and remote response to chronic interpersonal stress at work. It is a process that usually builds up gradually and is difficult to reverse. Nurses working with mentally ill patients are a high-risk group for developing professional burnout.

Objectives. The aims of the study were to evaluate the level of professional burnout in mental health nurses working in the Masovian voivodeship in Poland, and to identify stress-inducing factors.

Material and methods. The research, which was conducted in January and February 2017 using the diagnostic survey method, involved 107 mental health nurses employed in healthcare facilities located in the Masovian voivodeship. The research tool was a survey comprising of 2 questionnaires. The $1{ }^{15 t}$ was a modified Maslach Burnout Inventory (MBI), the $2^{\text {nd }}-$ Goldberg's General Health Questionnaire (GHQ-28) for mental health evaluation. The statistical analysis was conducted using the STATISTICA v. 13.1 program and the MBI questionnaires were evaluated with $x^{2}$ test, Kruskal -Wallis ANOVA and Mann-Whitney $U$ test. Values of $p<0.05$ were regarded as statistically significant.
\end{abstract}

Results. The statistical analysis of both questionnaires showed that the selected group of nurses is at risk of professional burnout. The research results showed that $51 \%$ of the interviewees were emotionally exhausted, while $46 \%$ admitted they are more or much more overtired than usual. Education level, age and job seniority also affected the mental health status of the respondents.

Conclusions. These findings show that the study group is prone to professional burnout. Younger nurses with higher education and shorter overall employment histories are significantly at risk of professional burnout.

Key words: psychiatry, work stress, professional burnout in nurses 


\section{Streszczenie}

Wprowadzenie. Wypalenie zawodowe pojawia się w sytuacji przewlekłego stresu i dotyczy przede wszystkim grup zawodowych, których istotą jest bliski, angażujący kontakt interpersonalny oraz bezpośrednia praca z ludźmi. Wypalenie zawodowe stanowi konsekwencję braku zgodności między osobą a środowiskiem pracy. To proces, który narasta stopniowo, często w sposób ukryty i trudny do odwrócenia. Pielęgniarki pracujące z chorymi psychicznie zaliczają się do grupy wysokiego ryzyka zespołu wypalenia zawodowego, ponieważ w codziennej pracy są w stałym kontakcie z ludźmi potrzebującymi specjalistycznej opieki.

Cel pracy. Próba oceny stopnia wypalenia zawodowego pielęgniarek psychiatrycznych pracujących na terenie województwa mazowieckiego oraz identyfikacji czynników stresogennych wpływających na to zjawisko.

Materiał i metody. Badanie przeprowadzono w styczniu i lutym 2017 r. i objęto nim 107 pielęgniarek psychiatrycznych zatrudnionych na terenie województwa mazowieckiego. Do realizacji badania posłużyła metoda sondażu diagnostycznego. Narzędziem badawczym była ankieta złożona z 2 kwestionariuszy. Pierwszym z nich był zmodyfikowany test Maslach Burnout Inventory (MBI) - Kwestionariusz Wypalenia Zawodowego Maslach, a drugim standaryzowany General Health Questionnaire-28 (GHQ-28) - Ocena Zdrowia Psychicznego według D. Goldberga. Analiza statystyczna została wykonana w programie STATISTICA 13.1. Do obliczenia wyników użyto testów: $x^{2}$, ANOVA Kruskala-Wallisa oraz testu U Manna-Whitneya, a za istotne statystycznie przyjęto odpowiedzi z poziomem $p<0,05$.

Wyniki. Analiza statystyczna obu kwestionariuszy wykazała, że badana grupa pielęgniarek psychiatrycznych jest narażona na zespół wypalenia zawodowego. Z interpretacji obu kwestionariuszy wynika, że 51\% ankietowanych jest emocjonalnie wyczerpanych. Aż 46\% badanych pielęgniarek przyznaje, że jest przemęczonych bardziej lub znacznie bardziej niż zwykle. W przypadku badanej grupy wykształcenie, wiek, a także staż pracy mają wpływ na stan zdrowia psychicznego, jak również na zjawisko wypalenia zawodowego.

Wnioski. Przeprowadzone badanie wykazało, że badana grupa jest narażona na zjawisko wypalenia zawodowego. Pielęgniarki najbardziej narażone na zjawisko wypalenia zawodowego mają wyższe wykształcenie i należą do młodszej grupy wiekowej.

Słowa kluczowe: psychiatria, stres zawodowy, wypalenie zawodowe pielęgniarek

\section{Introduction}

Currently the nursing profession is coming to prominence in healthcare, of which it is an essential part. It plays an important role in promoting health and preventing disease in various areas of human functioning. Nursing staff is the most numerous group of medical personnel employed in medical institutions, and plays a significant role in caring for healthy and ill people. ${ }^{1}$ The growth in the significance of professional nursing care is slowly changing the way society perceives this professional group. Society expects nurses to have broader knowledge and more skills than only some years ago. Nurses play a significant role in dealing with patients' mental health challenges. ${ }^{2}$

Mental burdens, low compensation, inefficient cooperation among medical staff, and difficult communication with patients and their families are important factors in the development of professional stress in nurses. ${ }^{3}$ Mental health nurses are particularly at risk because their work entails severe and long-term stress caused by patients' unpredictable behavior. The necessity of using direct coercion towards aggressive patients intensifies fear for one's own safety and is a strong indicator for the development of the burnout syndrome. Mental health patients are often reluctant to cooperate, do not want to take medication and may not consent to the treatment, and the period of their hospitalization tends to be long. ${ }^{4-7}$ Ineffective ways of coping with stress and a lack of support from others in difficult situations can lead to the burnout syndrome, which not only reduces the quality of work, but also precludes further professional development.

Professional burnout is a consequence of dissonance between a person and their working environment. It is a multidimensional and remote response to chronic interpersonal stress at work. It is a process that builds up gradually and steadily, and is usually difficult to reverse. A sense of physical and mental exhaustion is of particular importance for the employee's declining health. The initial symptoms of professional burnout are fatigue, irritability, persistent anger, and impersonal treatment of patients. ${ }^{4-7}$ A general malaise is usually associated with a change in appetite and may affect the employee's weight. Individuals who develop the burnout syndrome appear to have headaches and muscle pain, sleeping disorders, as well as gastric and cardiological problems. The prolonged state of tension and fatigue results in automatic behavior and a tendency toward stereotypical perception of the surrounding reality. ${ }^{8}$ Therefore, it is important to prevent this phenomenon in the workplace because of the effects on the employees' health and productivity, but also for the sake of the patients' wellbeing. ${ }^{9,10}$

This work aims to evaluate the level of professional burnout in mental health nurses working in healthcare facilities in the Masovian voivodeship in Poland, and to identify stress-inducing determinants that lead to burnout. 


\section{Material and methods}

The research was conducted in January and February 2017 on 107 mental health nurses employed in the Masovian voivodeship. Women accounted for $96.3 \%$ of the study group and men for $3.7 \%$. At the time of the survey, the average age of the respondents was 49.3 years. The most numerous group (48.6\%) were people between 41 and 50 years of age; people aged 50 and over accounted for $43 \%$ of the respondents; $8.4 \%$ of those surveyed were under 40 years of age (Fig. 1). The respondents' average length of employment in the profession was 25.8 years; $50.5 \%$ of the respondents had been in the nursing profession for 25 years or more. The average job seniority in the same workplace was 17.6 years; almost $37 \%$ of those surveyed had not changed their workplace for 20 years or longer.

The group's education level was as follows: $54.2 \%$ had secondary vocational education and $31.8 \%$ had a bachelor's degree, of which almost $29 \%$ had the title of Bachelor of Nursing. In total, $20.6 \%$ of the respondents had master's degree education, including $8.4 \%$ with master's degree in nursing (Fig. 2).

The diagnostic survey was the method used in this study. The research tool consisted of 2 questionnaires. The $1^{\text {st }}$ was a modified and simplified Maslach Burnout Inventory (MBI). The $2^{\text {nd }}$ was Goldberg's General Health Questionnaire (GHQ-28) for mental health evaluation, which is a screening test used to detect mental disorders and the respondent's general mental health status.

The statistical analysis was conducted using the STATISTICA v. 13.1 program (StatSoft Polska, Cracow, Poland). The MBI questionnaires were evaluated with the $X^{2}$ test, while the GHQ-28 responses were compared using the Kruskal-Wallis analysis of variance (ANOVA) test and Mann-Whitney $U$ test. Results at the level of $p<0.05$ were regarded as statistically significant.

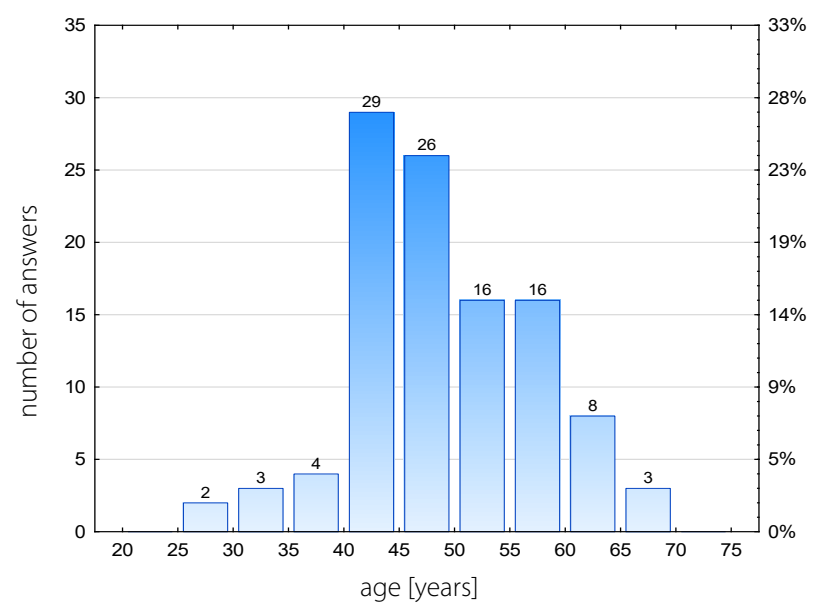

Fig. 1. Age distribution in the studied group

Ryc. 1. Rozkład wieku badanej grupy

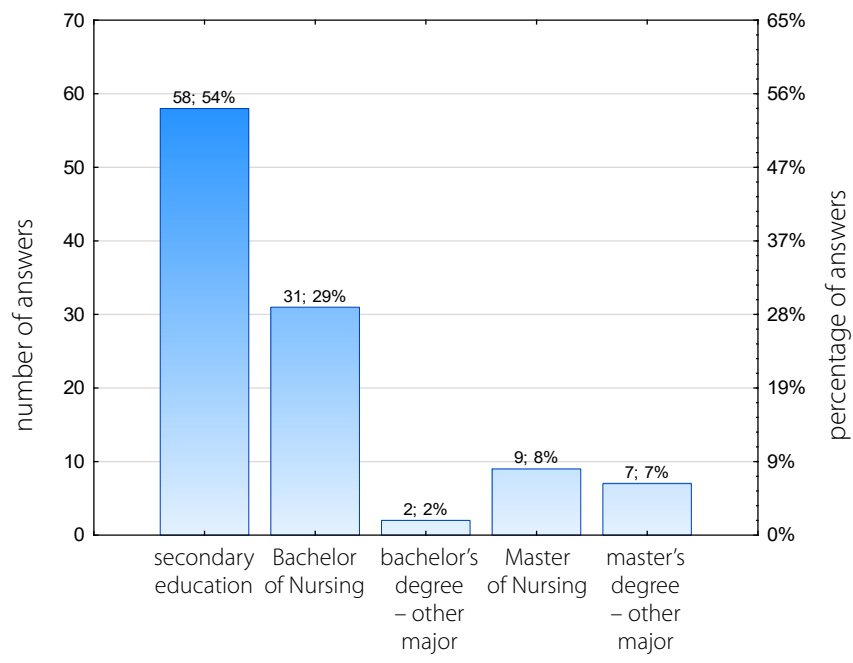

Fig. 2. Education level in the studied group

Ryc. 2. Wykształcenie badanej grupy

\section{Results}

The statistical analyses of both questionnaires showed that the group of mental health nurses examined was exhibiting signs of professional burnout. The survey showed that $51 \%$ of the respondents were emotionally exhausted (Fig. 3). Additionally, 70\% of the respondents declared that at the end of the day they feel "worn out" (Fig. 4). In total, $46 \%$ of the respondents felt more or much more overtired than usual (Fig. 5). Tension and nervousness were reported by a total of $83 \%$ of the respondents; $21 \%$ feel more nervous than usual and $2 \%$ much more nervous than usual (Fig. 6). Almost half of the nurses surveyed lack energy in their daily lives (Fig. 7). A total of $29 \%$ of respondents declare bigger or much bigger problems with falling asleep (Fig. 8) and 28\% of respondents suffer from more frequent headaches (Fig. 9).

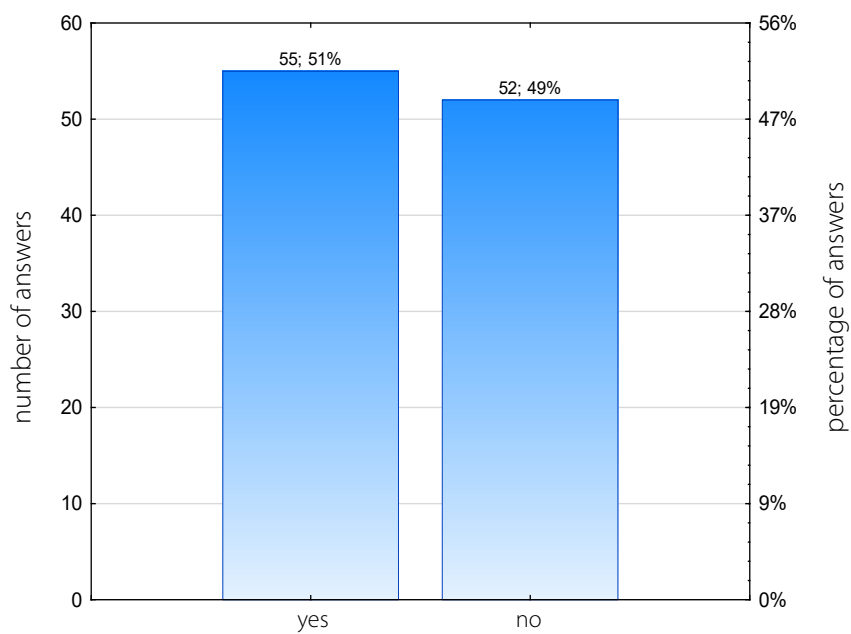

Fig. 3. Answers to the statement

"I feel emotionally exhausted because of my work"

Ryc. 3. Odpowiedzi na stwierdzenie

„Przez moją pracę czuję się emocjonalnie wyczerpany/wyczerpana” 


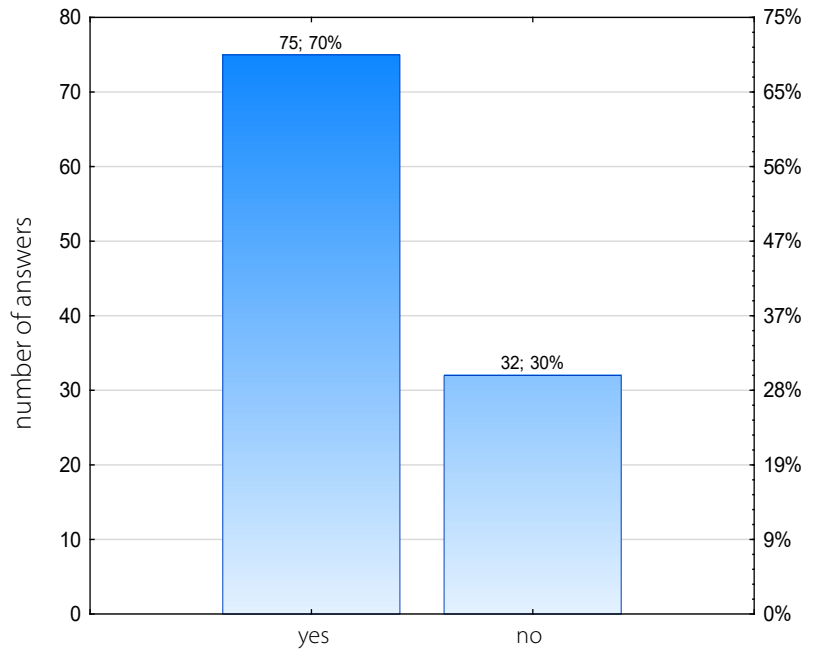

Fig. 4. Answers to the statement "At the end of the working day I feel worn out"

Ryc. 4. Odpowiedzi na stwierdzenie

"Na koniec dnia pracy czuję się zużyty/zużyta"

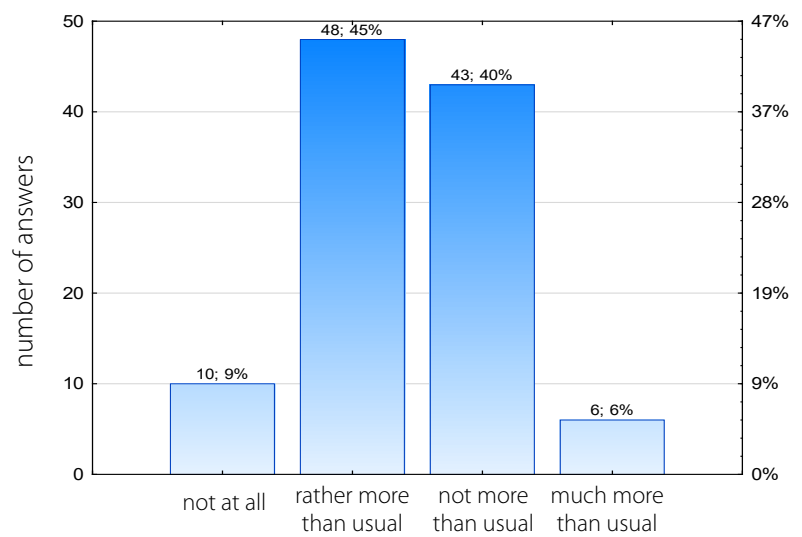

Fig. 5. Answers to the question "Have you ever felt constantly tired?"

Ryc. 5. Odpowiedzi na pytanie "Czy ostatnio czułeś/czułaś się stale przemęczony/przemęczona?"

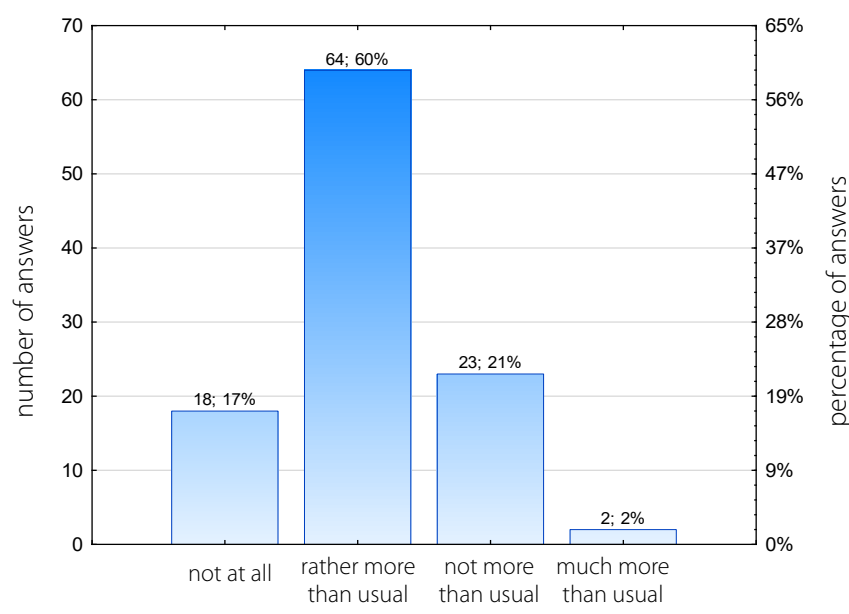

Fig. 6. Answers to the question "Did you recently feel upset and tense all the time?"

Ryc. 6. Odpowiedzi na pytanie „Czy ostatnio czułeś/czułaś się cały czas zdenerwowany/zdenerwowana i napięty/napięta?"

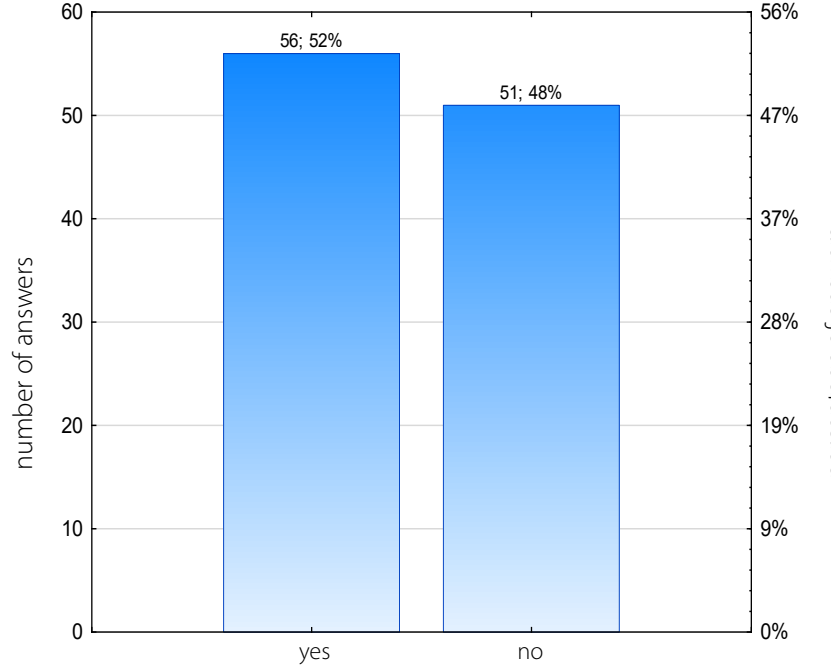

Fig. 7. Answers to the statement "I feel a lot of energy in me"

Ryc. 7. Odpowiedzi na stwierdzenie „Czuję w sobie duże pokłady energii”

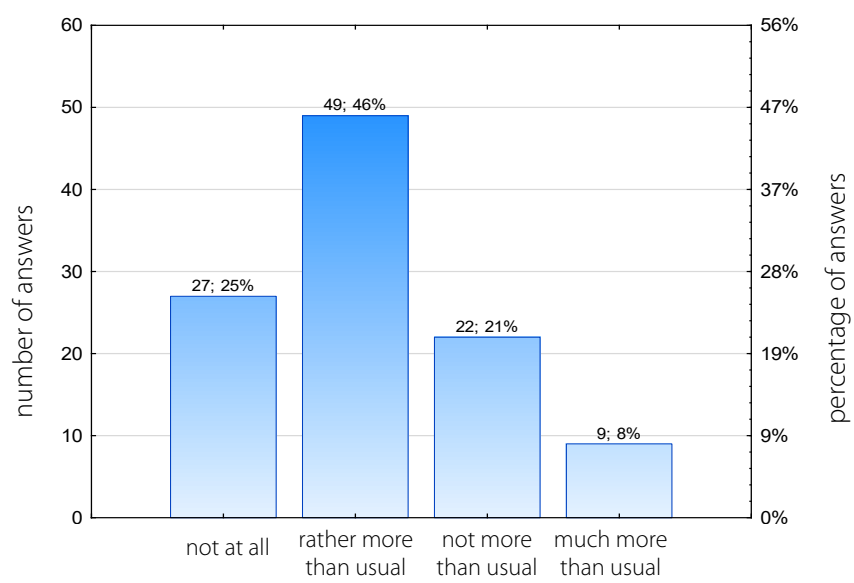

Fig. 8. Answers to the question

"Did you recently have difficulty falling asleep again after you woke up?"

Ryc. 8. Odpowiedzi na pytanie "Czy ostatnio miewałeś/miewałaś po przebudzeniu trudności z ponownym zaśnięciem?"

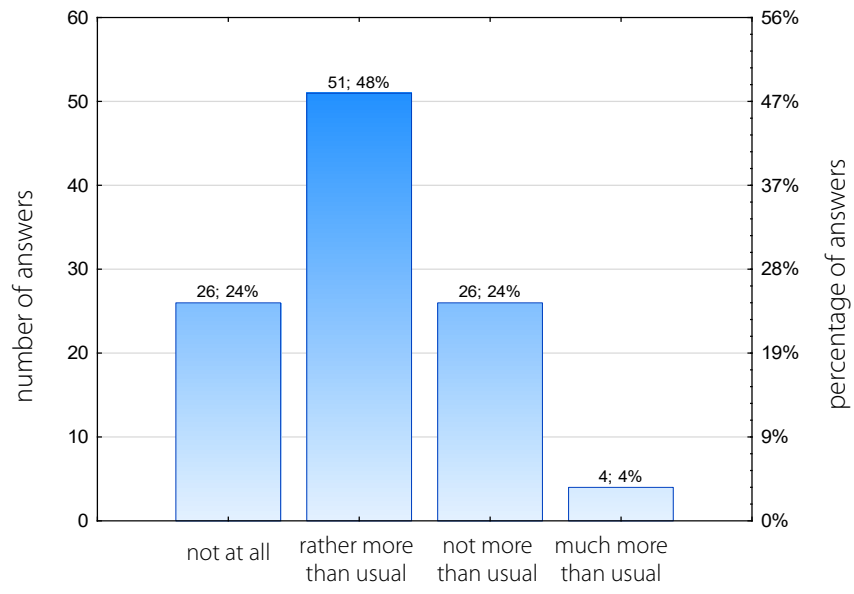

Fig. 9. Answers to the question "Have you had headaches lately?" Ryc. 9. Odpowiedzi na pytanie „Czy ostatnio miewałeś/miewałás bóle głowy?" 
The analysis of the questionnaire also showed that in the case of the surveyed group, education, age and job seniority have an impact on mental health as well as on professional burnout. The MBI Professional Burnout Questionnaire adapted to the needs of the study showed that nurses with higher education are much more exposed to occupational burnout, and the GHQ-28 questionnaire showed that nurses under 45 years of age and nurses with higher education are less resistant to stress.

The results of the questionnaire assessing the respondents' mental health status were divided into groups according to age, education, job seniority and seniority in a particular institution, and compared using the MannWhitney $U$ test. The number of points scored in part A of the questionnaire and the total sum of points were significantly higher in the group of nurses with higher education (Table 1). In other categories, the answers did not differ statistically. Table 2 presents the degree of occupational burnout depending on education.

Statistically, the answers given by nurses with higher education to questions about the situation of the patients they have looked after were significantly different. Nurses with higher education were 3 times more likely than those with secondary education to think that they have objectified patients (Table 3). The study also showed that work in direct contact with people exhausted nurses with higher education twice as much as those with secondary education (Table 4). Nurses in the 30-45-years-of-age group were 2.5 times more inclined to think that they are less compassionate and less interested in the patients' situation (Table 5). Differences are also noticeable in the responses of the respondents regarding solving the patients' problems. Older nurses are more convinced than their younger colleagues that they manage to effectively solve their patients' problems.

The answers regarding the achievement of career goals in the groups examined were also statistically significant. Nurses over 50 years of age were much more satisfied than their younger colleagues, and convinced that they have achieved more at work (Table 6). The length of time a respondent had spent in the nursing profession as well as seniority at a given workplace also affected the responses: Nurses with shorter service in the profession reported signs of burnout 6 times more frequently than those who had worked longer as nurses (Table 7). Those who had been working as nurses less than 20 years reported that they had become indifferent to people in their environment from the moment they started working in the nursing profession, and declared that they are not interested in the fate of their patients 3 times more often than nurses who had been in the profession longer (Table 8 ).

In terms of seniority in a given workplace, nurses who had less seniority in a given workplace responded twice as often that they feel tired with a new working day ahead of them. Among nurses with less seniority at their place of employment, $10.7 \%$ think that they have become indifferent to people since taking the job, while those with 20 years seniority or more denied becoming indifferent to people since taking the job (Table 9). Nurses with less seniority are twice as likely to fear that they are less compassionate and not concerned with the fate of the patients. Overall, $50 \%$ of the nurses surveyed think that some patients and their relatives consider nurses responsible for their problems (Fig. 10).

Issues related to compensation were also significant: $76 \%$ of the respondents believed that their salaries are

Table 1. The results of the questionnaire (number of points) assessing the respondents' state of mental health in relation with their level of education Tabela 1. Liczba punktów uzyskanych w kwestionariuszu oceniającym stan zdrowia psychicznego w zależności od wykształcenia pielęgniarek/pielęgniarzy

\begin{tabular}{|c|c|c|c|c|c|c|c|}
\hline $\begin{array}{l}\text { Part of the } \\
\text { questionnaire }\end{array}$ & Average & $\begin{array}{c}\text { Average secondary } \\
\text { education }\end{array}$ & $\begin{array}{l}\text { Average higher } \\
\text { education }\end{array}$ & $\begin{array}{c}\text { Average ranks } \\
\text { secondary } \\
\text { education }\end{array}$ & $\begin{array}{l}\text { Average ranks } \\
\text { higher education }\end{array}$ & $Z$ & $p$-value \\
\hline A - points & 2.50 & 2.02 & 3.08 & 47.47 & 61.72 & 2.36 & 0.02 \\
\hline B - points & 2.06 & 1.76 & 2.41 & 49.21 & 59.67 & 1.74 & 0.08 \\
\hline$C$ - points & 1.22 & 1.02 & 1.47 & 51.71 & 56.71 & 0.83 & 0.41 \\
\hline$D$ - points & 0.56 & 0.55 & 0.57 & 53.68 & 54.38 & 0.11 & 0.91 \\
\hline$A B C D$ - total & 6.35 & 5.34 & 7.53 & 48.01 & 61.09 & 2.17 & 0.03 \\
\hline
\end{tabular}

Table 2. The points scored in the questions assessing the degree of burnout in relation with the nurses' level of education

Tabela 2. Suma punktów uzyskanych w pytaniach oceniających stopień wypalenia zawodowego w zależności od wykształcenia pielęgniarek/pielęgniarzy

\begin{tabular}{|l|c|c|c|c|c|} 
Part of the & Average number \\
questionnaire & $\begin{array}{c}\text { Average secondary } \\
\text { education }\end{array}$ & $\begin{array}{c}\text { Average higher } \\
\text { education }\end{array}$ & $\begin{array}{c}\text { Average ranks } \\
\text { secondary } \\
\text { education }\end{array}$ & $\begin{array}{c}\text { Average ranks } \\
\text { higher education }\end{array}$ & $\begin{array}{c}Z \\
\boldsymbol{z} \text {-value }\end{array}$ \\
\hline Total 1-14 & 4.82 & 3.91 & 5.90 & 46.16 & 63.28 \\
Total 15-22 & 3.34 & 3.02 & 3.71 & 49.73 & -2.84 \\
Total 1-22 & 8.16 & 6.93 & 9.61 & 45.93 & -1.54 \\
\hline
\end{tabular}


Table 3. The number of responses to the statement "I have the impression that I treat some patients as if they were objects" in relation to the nurses' level of education

Tabela 3. Liczba odpowiedzi na stwierdzenie "Mam wrażenie, że traktuję niektórych pacjentów, jakby byli przedmiotami" w zależności od wykształcenia pielęgniarek/pielęgniarzy

\begin{tabular}{|l|r|r|r|r|r|r|r|}
\multirow{2}{*}{ Answer } & \multicolumn{2}{|c|}{$\begin{array}{c}\text { Secondary } \\
\text { education }\end{array}$} & \multicolumn{2}{|c|}{$\begin{array}{c}\text { Higher } \\
\text { education }\end{array}$} & \multirow{2}{*}{ Total } & $x^{2}$ & $p$-value \\
\cline { 2 - 6 } & \multicolumn{1}{|c|}{$n$} & $\%$ & $n$ & $\%$ & & & \\
Yes & 5 & 8.62 & 14 & 28.57 & 19 & & \\
No & 53 & 91.38 & 35 & 71.43 & 88 & 7.2392 & 0.0071 \\
Total & 58 & 100.00 & 49 & 100.00 & 107 & & \\
\hline
\end{tabular}

$n$ - number of the analyzed characteristic in the sample.

Table 4. The number of responses to the statement "Working with people all day is very tiring for me" in relation to the nurses' level of education

Tabela 4. Liczba odpowiedzi na stwierdzenie „Bardzo mnie wyczerpuje całodzienna praca z ludźmi" w zależności od wykształcenia pielęgniarek/ pielęgniarzy

\begin{tabular}{|l|c|c|c|c|c|c|c|}
\multirow{2}{*}{ Answer } & \multicolumn{2}{|c|}{$\begin{array}{c}\text { Secondary } \\
\text { education }\end{array}$} & \multicolumn{2}{|c|}{$\begin{array}{c}\text { Higher } \\
\text { education }\end{array}$} & \multirow{2}{*}{ Total } & $x^{2}$ & $p$-value \\
\cline { 2 - 6 } & \multicolumn{1}{|c|}{$n$} & $\%$ & $n$ & $\%$ & & & \\
\hline Yes & 13 & 22.41 & 21 & 42.86 & 34 & & \\
No & 45 & 77.59 & 28 & 57.14 & 73 & 5.1205 & 0.0237 \\
Total & 58 & 100.00 & 49 & 100.00 & 107 & & \\
\hline
\end{tabular}

Table 5. The number of answers to the statement "I am afraid that my work makes me less compassionate" in relation to the age of the nurses

Tabela 5. Liczba odpowiedzi na stwierdzenie „Obawiam się, że moja praca czyni mnie mniej współczującym" w zależności od wieku pielęgniarek/ pielęgniarzy

\begin{tabular}{|l|c|c|c|c|c|c|c|}
\multirow{2}{*}{ Answer } & \multicolumn{2}{|c|}{$\begin{array}{l}\text { Age }<50 \\
\text { years }\end{array}$} & \multicolumn{2}{|c|}{$\begin{array}{c}\text { Age } \\
\geq 50 \text { years }\end{array}$} & Total & $x^{2}$ & $p$-value \\
\cline { 2 - 9 } & \multicolumn{1}{|c|}{$n$} & $\%$ & \multicolumn{1}{c|}{$n$} & $\%$ & & & \\
\hline Yes & 24 & 41.38 & 9 & 18.37 & 33 & & \\
No & 34 & 58.62 & 40 & 8.63 & 74 & 6.5943 & 0.0102 \\
Total & 58 & 100.00 & 49 & 100.00 & 107 & & \\
\hline
\end{tabular}

Table 6. The number of responses to the statement "I manage to effectively solve my patients' problems" in relation to the age of nurses

Tabela 6. Liczba odpowiedzi na stwierdzenie „Udaje mi się skutecznie rozwiązywać problemy moich pacjentów" w zależności od wieku pielęgniarek/pielęgniarzy

\begin{tabular}{|c|c|c|c|c|c|c|c|}
\hline \multirow[t]{2}{*}{ Answer } & \multicolumn{2}{|c|}{$\begin{array}{c}\text { Age } \\
<50 \text { years }\end{array}$} & \multicolumn{2}{|c|}{$\begin{array}{c}\text { Age } \\
\geq 50 \text { years }\end{array}$} & \multirow[t]{2}{*}{ Total } & \multirow{2}{*}{$x^{2}$} & \multirow[t]{2}{*}{$p$-value } \\
\hline & $n$ & $\%$ & $n$ & $\%$ & & & \\
\hline Yes & 25 & 43.10 & 31 & 63.27 & 56 & \multirow{3}{*}{4.3282} & \multirow{3}{*}{0.0375} \\
\hline No & 33 & 56.90 & 18 & 3673 & 51 & & \\
\hline Total & 58 & 100.00 & 49 & 100.00 & 107 & & \\
\hline
\end{tabular}

important in their lives and 98\% declared that their compensation is too low (Fig. 11, 12).

The analysis of the GHQ-28 questionnaire showed that the group of nurses examined is exposed to stress.
Table 7. Number of responses to the statement "I have become indifferent to people since I've been doing this job" in relation to the number of years in the nursing profession

Tabela 7. Liczba odpowiedzi na stwierdzenie „Stałem/stałam się obojętny/ obojętna wobec ludzi, odkąd wykonuję tę pracę" w zależności od liczby lat w zawodzie pielęgniarki/pielęgniarza

\begin{tabular}{|l|r|r|r|r|r|r|r|}
\multirow{2}{*}{ Answer } & \multicolumn{2}{|c|}{$\begin{array}{c}\text { Job seniority } \\
<25 \text { years }\end{array}$} & $\begin{array}{c}\text { Job seniority } \\
\geq 25\end{array}$ & years & Total & $X^{2}$ & $p$-value \\
\cline { 2 - 6 } & \multicolumn{1}{|c|}{$n$} & $\%$ & $n$ & $\%$ & & & \\
\hline Yes & 6 & 11.32 & 1 & 1.85 & 7 & & \\
No & 47 & 88.68 & 53 & 98.15 & 100 & 3.9224 & 0.0477 \\
Total & 53 & 100.00 & 54 & 100.00 & 107 & & \\
\hline
\end{tabular}

Table 8. Number of responses to the statement "In fact, I'm not interested in what will happen to some patients" in relation to the number of years in the nursing profession

Tabela 8. Liczba odpowiedzi na stwierdzenie „W rzeczywistości nie interesuje mnie, co się stanie z niektórymi pacjentami” w zależności od liczby lat w zawodzie pielęgniarki/pielęgniarza

\begin{tabular}{|c|c|c|c|c|c|c|c|}
\hline \multirow[t]{2}{*}{ Answer } & \multicolumn{2}{|c|}{$\begin{array}{c}\text { Job seniority } \\
<25 \text { years }\end{array}$} & \multicolumn{2}{|c|}{$\begin{array}{c}\text { Job seniority } \\
\geq 25 \text { years }\end{array}$} & \multirow[t]{2}{*}{ Total } & \multirow{2}{*}{$x^{2}$} & \multirow{2}{*}{$p$-value } \\
\hline & $n$ & $\%$ & $n$ & $\%$ & & & \\
\hline Yes & 23 & 43.40 & 8 & 14.81 & 31 & \multirow{3}{*}{10.6181} & \multirow{3}{*}{0.0011} \\
\hline No & 30 & 56.60 & 46 & 85.19 & 76 & & \\
\hline Total & 53 & 100.00 & 54 & 100.00 & 107 & & \\
\hline
\end{tabular}

Table 9. Number of responses to the statement "I have become indifferent to people since I took this job" in terms of the nurses' seniority at a given place of work

Tabela 9. Liczba odpowiedzi na stwierdzenie „W rzeczywistości nie interesuje mnie, co się stanie z niektórymi pacjentami" w zależności od stażu w danym miejscu pracy

\begin{tabular}{|l|c|c|c|c|c|c|c|}
\multirow{2}{*}{ Answer } & $\begin{array}{c}\text { Seniority } \\
\text { at the } \\
\text { workplace } \\
<20 \text { years }\end{array}$ & $\begin{array}{c}\text { Seniority } \\
\text { at the } \\
\text { workplace } \\
\geq 20 \text { years }\end{array}$ & Total & $x^{2}$ & $p$-value \\
\cline { 2 - 8 } & $n$ & $\%$ & $n$ & $\%$ & & & \\
\hline Yes & 7 & 10.77 & 0 & 0.00 & 7 & & \\
No & 58 & 89.23 & 42 & 100.00 & 100 & 4.8397 & 0.0278 \\
Total & 65 & 100.00 & 42 & 100.00 & 107 & & \\
\hline
\end{tabular}

Younger and better educated nurses are also less resistant to stress. Overall, $6 \%$ of the respondents confessed to suicidal thoughts (Fig. 13). The number of points scored in the part of the questionnaire concerning stress and the total number of points were significantly higher in the group of nurses with higher education.

Professional burnout is widespread among mental health nurses. The study shows that about half of the respondents experience work-related stress. The lowest level of professional burnout prevailed among nurses aged 50 and above. High levels of professional burnout were observed in nurses in the 30-45-years-of-age group, in which the nurses most often had higher education. High levels of professional stress also appeared 


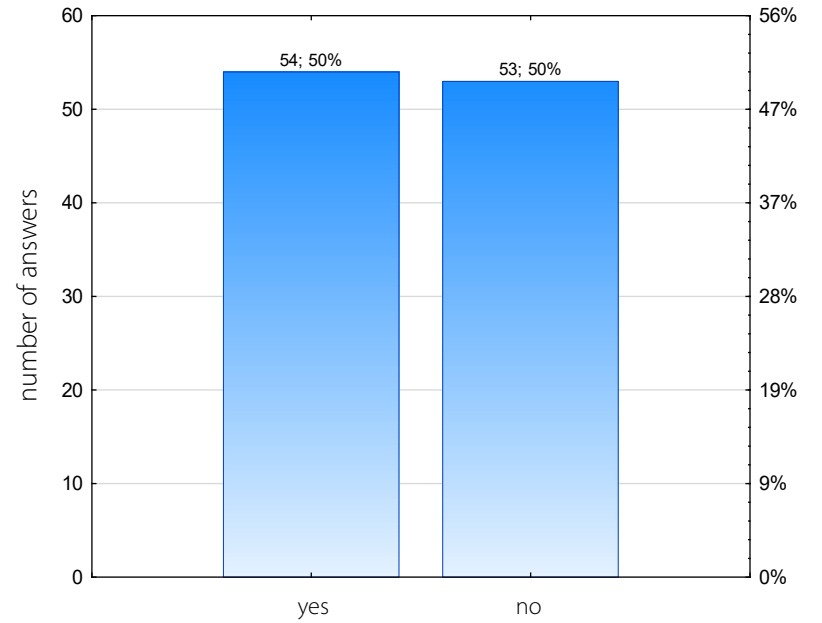

Fig. 10. Answers to the statement "I have the impression that some patients and their relatives think that I am responsible for their problems"

Ryc. 10. Odpowiedzi na stwierdzenie "Mam wrażenie, że niektórzy pacjenci i ich krewni sądzą, iż to ja ponoszę odpowiedzialność za ich problemy"

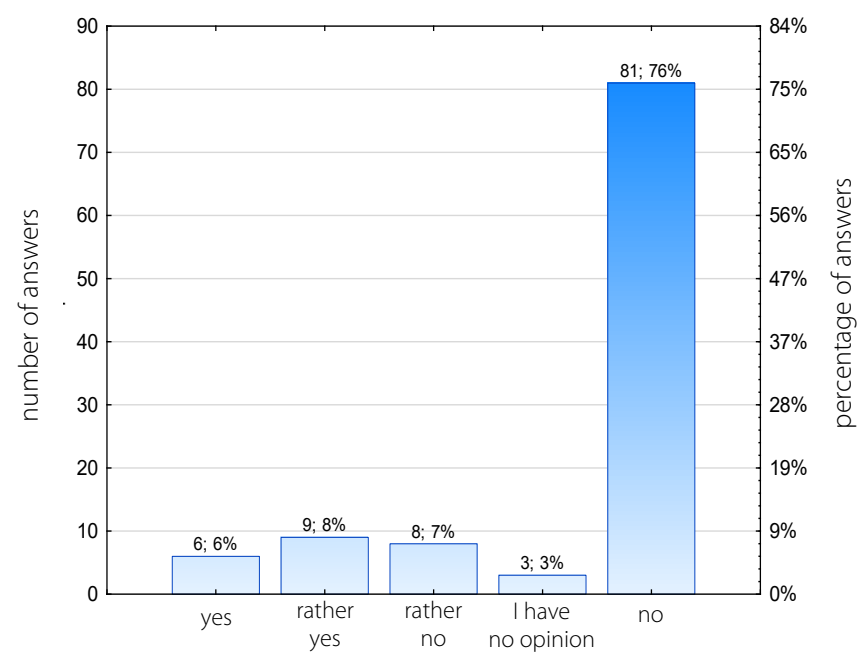

Fig. 11. Answers to the question "Some people claim that the amount of remuneration for work is irrelevant - they work not for money. Can you say the same about yourself?"

Ryc. 11. Odpowiedzi na pytanie „Niektóre osoby twierdzą, że wysokość wynagrodzenia za pracę jest nieistotna - pracują nie dla pieniędzy. Czy może Pan/Pani to samo powiedzieć o sobie?"

among nurses with brief work experience (1-12 years). A statistically significant correlation was found between mental health nurses' level of education and the phenomenon of professional burnout. However, it should be noted that in the case of nurses, education is related to age: Nurses under 50 usually have higher education, whereas older ones have secondary education, due to a change in the education system. Therefore, these 2 age groups were analyzed separately, and in both age groups nurses with higher education scored significantly more points on questions evaluating burnout.

A study conducted by Nowakowska and Rasińska on a group of 405 respondents employed in various hospital

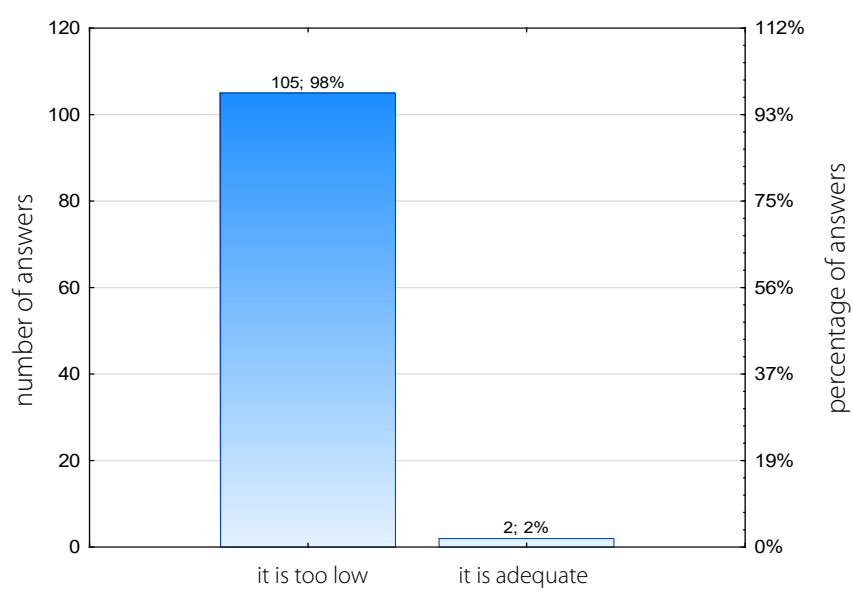

Fig. 12. Relation to the amount of own salary. Answers to the question "Please, mark the right answer"

Ryc. 12. Stosunek do wysokości własnego wynagrodzenia. Odpowiedzi na pytanie „Proszę zaznaczyć właściwą odpowiedź”

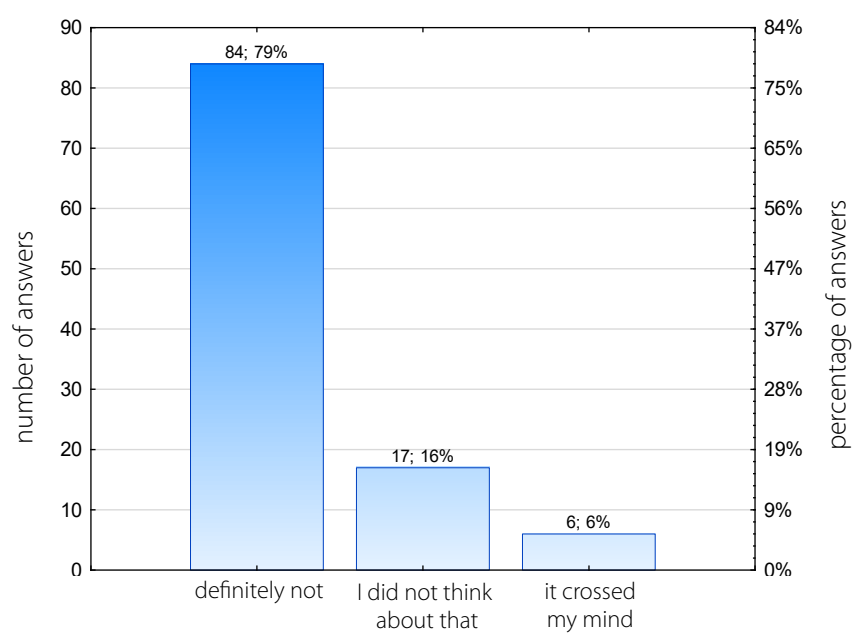

Fig. 13. Answers to the question "Have you recently thought about the possibility of taking your own life?"

Ryc. 13. Odpowiedzi na pytanie „Czy ostatnio myślałeś/myślałaś o możliwości odebrania sobie życia?"

departments, including psychiatric departments, showed that $48 \%$ of the respondents were at risk of occupational burnout: $74 \%$ of the respondents experienced burnout symptoms in contact with patients. ${ }^{11}$ As in the current study, this finding correlates with shorter work experience.

From a study conducted by Klejda and Szewczyk, which included a group of 50 nurses working in 1 hospital in the Lublin voivodeship in Poland, the respondents considered their work environment stress-inducing. Job satisfaction was felt by $64 \%$, while $36 \%$ were not satisfied with their job; in the self-assessment, $12 \%$ declared that they were experiencing professional burnout and that they were burdened by excessive work and problematic personal lives. Emotional exhaustion affected $30 \%$ of the respondents. ${ }^{12}$ Divisions into age, education and work experience were not taken into account in that study. 
A study carried out by Grzywna and Cieślik on 70 nures who work in mental health departments showed that $87.1 \%$ of the respondents consider their work environment stress-inducing. The risk of physical danger was the main source of stress for $83 \%$ of the respondents. The nurses surveyed also identified stressful interpersonal relationships as a problem in their work environment. The most stressful were relations with the patients' families (41.4\%) and with the patients themselves (35.7\%). Most of the respondents (80\%) said that at the end of the day they feel worn out, and nearly $23 \%$ of the respondents felt that everyday work with people is exhausting. ${ }^{13}$

While analyzing the literature reporting the results of empirical research, the influence of socio-demographic factors on the appearance of symptoms of occupational burnout was noted. The most frequently mentioned factors are age, sex, education, marital status, and job seniority. According to Maslach et al., nurses employed longer at a given institution more often experience burnout related to work and contact with patients, whereas nurses with less seniority are more exposed to personal burnout. ${ }^{14}$ In the present study, this thesis was confirmed in the case of employees working for shorter periods.

\section{Conclusions}

The study showed that the group of mental health nurses examined was exposed to professional burnout. Higher education was the factor that most strongly correlated with professional burnout in this group of respondents.

The results of the survey indicate that nurses aged between 25 and 45 are more exposed to stress and professional burnout. Employees under 45 years of age are more affected by the burnout syndrome.

In the study group, fatigue and exhaustion were the most frequent somatic symptoms of burnout.

Insufficient compensation affects the nurses' level of dissatisfaction and has an indirect impact on the development of burnout.

Because younger nurses with less job seniority display more features of professional burnout, attention should be paid to the environment in which they start their work in the profession - whether it is favorable and friendly or unwilling to accept new, usually better educated nurses. Or maybe nurses starting out in the profession have excessively high expectations? This phenomenon requires a deeper analysis of the subject.

\section{ORCID iD}

Aleksandra Łucja Łopatkiewicz (1) https://orcid.org/0000-0002-8156-1103

\section{References}

1. Perneger TV, Staines A, Kundig F. Internal consistency, factor structure and construct validity of the French version of the Hospital Survey on Patient Safety Culture. BMJ Qual Saf. 2014;23(5):389-397. doi:10.1136/bmjqs-2013-002024

2. The Health Foundation. Measuring Safety Culture. http://www .health.org.uk/sites/default/files/MeasuringSafetyCulture.pdf. London, UK: The Health Foundation; 2011.

3. Arain M, Campbell MJ, Cooper CL, Lancaster GA. What is a pilot or feasibility study? A review of current practice and editorial policy. BMC Med Res Methodol. 2010;10:67. doi:10.1186/1471-2288-10-67

4. Sorra JS, Dyer N. Multilevel psychometric properties of the AHRQ hospital survey on patient safety culture. BMC Health Serv Res. 2010;10:199. doi:10.1186/1472-6963-10-199

5. Sarac C, Flin R, Kathryn Mearns K, et al. Hospital survey on patient safety culture: Psychometric analysis on a Scottish sample. BMJ Qual Saf. 2011;20(10):842-848. doi:10.1136/bmjqs.2010.047720

6. Sorra J, Gray L, Streagle S, et al. AHRQ Hospital Survey on Patient Safety Culture: User's Guide. (Prepared by Westat, under Contract No. HHSA290201300003C). AHRQ Publication No. 15-0049-EF (Replaces 04-0041). Rockville, MD: Agency for Healthcare Research and Quality. January 2016. http://www.ahrq.gov/professionals /quality-patient-safety/patientsafetyculture/hospital/index.html. Accessed on January 3, 2020.

7. Fan W, Yan Z. Factors affecting response rates of the web survey: A systematic review. Comput Human Behav. 2010;26(2):132-139. doi:10.1016/j.chb.2009.10.015

8. Smits $M$, Dingelhoff IC, Wagner $C$, et al. The psychometric properties of the Hospital Survey on Patient Safety Culture in Dutch hospitals. BMC Health Serv Res. 2008;8:230.

9. Robida A. Hospital Survey on Patient Safety Culture in Slovenia: A psychometric evaluation. Int J Qual Health Care. 2013;25(4): 469-475. doi:10.1093/intahc/mzt040

10. Olsen E. Reliability and validity of the hospital survey on patient safety culture at a Norwegian hospital. In: Øvretveit J, Sousa P, eds. Quality and Safety Improvement Research. Lisbon, Portugal: National School of Public Health; 2008:173-186.

11. Nowakowska I, Rasińska R. Związek wybranych czynników socjodemograficznych z wypaleniem zawodowym wśród pielęgniarek. Piel Pol. 2014;1(51):26-33. http://www.pielegniarstwo.ump.edu.pl /article.php?id=4. Accessed on January 3, 2020.

12. Klejda A, Szewczyk L. Syndrom wypalenia zawodowego w pracy pielęgniarek psychiatrycznych. Aspekty Zdrowia $i$ Choroby. 2016;1(1):21-29. http://www.wydawnictwo.wsei.eu/index.php /azch/article/view/363. Accessed on January 3, 2020.

13. Grzywna T, Cieślik A. Praca pielęgniarki w oddziale psychiatrycznym zamkniętym a zespół wypalenia zawodowego. Ann UMCS Sect D. 2003;13(86):465-469.

14. Maslach C, Shaufeli WB, Leiter MP. Job burnout. Ann Rey Psychol. 2001;51:397-422. doi:10.1146/annurev.psych.52.1.397 